\title{
Pharmacokinetics of 10-gingerol and 6-shogaol in the plasma of healthy subjects treated with red ginger (Zingiber officinale var. Rubrum) suspension
}

\author{
JUTTI LEVITA $^{1}$, DINA MULYANA SYAFITRI ${ }^{1,2}$, RINI DAUD SUPU $^{1,3}$, \\ MUTAKIN MUTAKIN $^{4}$, SANDRA MEGANTARA ${ }^{4}$, MAYA FEBRIANTI ${ }^{5}$ and AJENG DIANTINI ${ }^{2}$ \\ ${ }^{1}$ Department of Pharmacology and Clinical Pharmacy, Faculty of Pharmacy, Padjadjaran University, \\ Jatinangor, West Java 45363; ${ }^{2}$ Clinical Pharmacy, Riau Islands General Hospital, Tanjung Pinang, \\ Riau Islands 29125; ${ }^{3}$ School of Health Science (STIKES) Bina Mandiri Gorontalo, Gorontalo,
} North Sulawesi 96128; ${ }^{4}$ Department of Pharmaceutical Analysis and Medicinal Chemistry, and ${ }^{5}$ Department of Biological Pharmacy, Faculty of Pharmacy, Padjadjaran University, Jatinangor, West Java 45363, Indonesia

Received May 3, 2018; Accepted October 19, 2018

DOI: $10.3892 /$ br.2018.1163

\begin{abstract}
Red ginger (Zingiber officinale var. Rubrum) is among the most widely consumed medicinal herbs in Indonesia. Ginger rhizome contains phenol compounds including gingerol and shogaol. 10-gingerol has been reported to exhibit the greatest anti-inflammatory and anti-oxidant activities compared with those of other gingerols. Pharmacokinetic studies on ginger have been reported, but there is a lack of such study on red ginger. The present work studied the pharmacokinetics of 10-gingerol and 6-shogaol in the plasma of healthy subjects treated with a single dose of red ginger suspension. Healthy subjects $(n=19)$ were given a single dose of red ginger suspension $(2 \mathrm{~g} / 15 \mathrm{ml})$, and blood samples were taken at baseline ( $0 \mathrm{~min}), 30,60,90,120$, and $180 \mathrm{~min}$. Analysis of 10-gingerol and 6-shogaol was performed by dissolving $200 \mu \mathrm{l}$ of the subjects' plasma in $800 \mu$ l acetonitrile. The mixture was vortexed and centrifuged at 20,440 x g for $15 \mathrm{~min}$ at room temperature. The supernatant was filtered using Millipore membrane (pore size $0.2 \mu \mathrm{m}$ ) and injected into an RP-C18 column for liquid chromatography-mass spectrometry. A mixture of $0.1 \%(\mathrm{v} / \mathrm{v})$ formic acid in water and acetonitrile (38:62) was used as the mobile phase. The maximum plasma concentration (Cmax) and time to reach $\mathrm{Cmax}$ of 10-gingerol and 6-shogaol were $160.49 \mathrm{ng} / \mathrm{ml}$ (38 $\mathrm{min}$ ) and $453.40 \mathrm{ng} / \mathrm{ml}$ (30 min), respectively. The elimination half-lives were 336 and $149 \mathrm{~min}$ for 10 -gingerol and 6-shogaol, respectively. Thus,
\end{abstract}

Correspondence to: Professor Jutti Levita, Department of Pharmacology and Clinical Pharmacy, Faculty of Pharmacy, Padjadjaran University, Jl. Raya Bandung-Sumedang km 21, Jatinangor, West Java 45363, Indonesia

E-mail: jutti.levita@unpad.ac.id

Key words: antiinflammation, gingerol, oleoresins, phenols, shogaol, Zingiberaceae, Zingiber officinale var. Rubrum 10-gingerol and 6-shogaol were absorbed after per oral single dose of red ginger suspension and could be quantified in the plasma of the healthy subjects. Additionally, the red ginger analytes exhibited relatively slow elimination half-lives.

\section{Introduction}

Several studies have reported on the concentration of gingerols in fresh ginger (Zingiber officinale var. Roscoe) rhizomes, for instance, the methanol extract of $Z$. officinale var. Roscoe rhizome cultivated in Hawaii contained 6-, 8- and 10-gingerol at concentrations of 2,100, 288 and $533 \mu \mathrm{g} / \mathrm{g}$, respectively (1); the methylene chloride extract of $Z$. officinale var. Roscoe rhizome cultivated in America yielded 880, 93 and $120 \mu \mathrm{g} / \mathrm{g}$ of 6-, 8- and 10-gingerol, respectively (2); and the fresh rhizome of Z. officinale var. Roscoe cultivated in Taiwan contained 806 $\mu \mathrm{g} / \mathrm{g}$ of 6-gingerol (3). Furthermore, phytochemical screening of the chloroform extract of Z. officinale var. Roscoe rhizome cultivated in Pakistan has given positive results on the presence of alkaloid, phlobotannins, flavonoids, glycosides, saponins, tannin and terpenoids, while indicating the absence of steroids (4). Alkaloids, carbohydrates, glycosides, proteins, saponins, steroids, flavonoids and terpenoids has been identified in Z. officinale var. Roscoe, and phenolic compounds including gingerol and shogaol (5-7), while reducing sugars, tannins, oils and acid compounds were absent. Similarly, results of proximate analysis of the rhizome have indicated mostly carbohydrates $(71.46 \%)$ and crude protein $(8.83 \%)$ with a small crude fibre content of $0.92 \%$ (5).

A comparative study of $Z$. officinale var. Roscoe pulp and peel demonstrated that the hydro-alcoholic extract of the peel exhibited marked inhibition of the growth of colon cancer cells on MTT assay, while the pulp extract exhibited high anti-inflammatory and antioxidant activities, allegedly due to differing polyphenolic content and lipophilic composition (8). Data on the effects of $Z$. officinale var. Roscoe have been reviewed, and it has been concluded that the rhizome of this plant has potential as an anti-inflammatory and anti-oxidative 
source, nonetheless further research has been suggested prior to confirming its efficacy (9). The medicinal properties of $Z$. officinale var. Roscoe may be due to the presence of gingerol, paradol and shogaols, among other compounds (10).

Gingerols are homologues of 1-(3-methoxy-4-hydroxy phenyl)-3-keto-5-hydroxyhexane, shogaols are dehydration products of the gingerols, and paradols are $\beta$-ketone hydroxyl deoxygenation products of gingerols (11). In previous studies $Z$. officinale var. Roscoe has exhibited anti-inflammatory activity (8,12-16). 10-gingerol (Fig. 1A) has been reported to exhibit the highest anti-inflammatory and anti-oxidant activities compared with those of other gingerols (17). Other studies on 6-gingerol have confirmed its inhibition of nitric oxide production in activated J774.1 mouse macrophages and prevention of peroxynitrite-induced oxidation and nitration reactions (18). This compound may also inhibit cyclooxygenase (COX)-2 expression by blocking the activation of p38 mitogen-activated protein kinase and nuclear factor- $\kappa \mathrm{B}$ in phorbol ester-stimulated mouse skin (19). However, studies on the effects of red ginger (Z. officinale var. Rubrum) are limited.

Previous study by Fikri et al (20) concluded that the hot water extract of $Z$. officinale var. Rubrum rhizome inhibited the rate of prostaglandin production in vitro. Furthermore, a computational study of gingerol and shogaol against COX enzymes reported that 6-gingerol and 6-shogaol were preferential COX-2 inhibitors and therefore potential candidates for development into anti-inflammatory drugs (21). Pharmacokinetic studies of the dry extract of ginger rhizomes (at doses of $100 \mathrm{mg}$ to $2 \mathrm{~g}$ ) in the plasma of healthy American volunteers have been conducted $(22,23)$. However, there is a lack of reports on red ginger. Thus, the present work studied the pharmacokinetics of 10-gingerol (Fig. 1A) and 6-shogaol (Fig. 1B) in the plasma of healthy Indonesian volunteers treated with a single dose $(2 \mathrm{~g})$ of red ginger suspension. The aims of this study were to: i) Determine if red ginger suspension is absorbed and biotransformed in humans; and ii) assess the human pharmacokinetics of 10-gingerol and 6-shogaol.

\section{Materials and methods}

Instruments. Instruments used in the study were a liquid chromatography-mass spectrometry (LC-MS) XEVO-QTOF MS (Waters-MassLynx 4.1 SCN719; PT Kromtekindo Utama, Jakarta, Indonesia) equipped with an RP-C18 column (2.1 x $100 \mathrm{~mm})$, a UV-visible double beam spectrophotometer (Specord 200; Analitik Jena AG, Jena, Germany), a digital analytical balance [Ohaus Pioneer; Ohaus Instruments (Shanghai) Co., Ltd., Shanghai, China], an Eppendorf Centrifuge $5424 \mathrm{R}$, a vortex mixer (Cole-Parmer, Vernon Hills, IL, USA), a dipotassium ethylenediamine tetraacetic acid (K2EDTA) tube (BD Vacutainer; BD Biosciences, Franklin Lakes, NJ, USA) and chemical glasswares.

Chemicals and plant materials. 10-gingerol of standard $98 \%$ purity (Sigma-Aldrich; Merck KGaA, Darmstadt, Germany; CAS no. 23513-15-7) and 6-shogaol of standard 98\% purity (Sigma-Aldrich; CAS no. 555-66-8) were purchased from Quartiz Indonesia (PT Indogen Intertama, Jakarta, Indonesia); methanol hypergrade for LC-MS (LiChrosolv ${ }^{\circledR}$; CAS no. 67-56-1) and acetonitrile gradient grade for liquid chromatography (LiChrosolv ${ }^{\circledR}$ CAS no. 75-05-08) were purchased from the Central Laboratory of Padjadjaran University (Jatinangor, West Java, Indonesia); and $1 \mathrm{~kg}$ of fresh rhizome of $Z$. officinale var. Rubrum was purchased from the Research Institute for Spices and Medicinal Plants (Balittro) Manoko Lembang (Bandung, Indonesia). The fresh rhizome was taxonomically identified at the Laboratory of Plant Taxonomy, Department of Biology, Faculty of Mathematics and Natural Sciences, Padjadjaran University, and the voucher specimen (no. 415/HB/08/2017) was retained in our laboratory for future reference.

Preparation of red ginger (Zingiber officinale var. Rubrum) suspension. The $1 \mathrm{~kg}$ of fresh rhizome of $Z$. officinale var. Rubrum was thin-sliced (1-2 mm) and dried in a dehydrator at $50^{\circ} \mathrm{C}$ for $4 \mathrm{~h}$. The dried rhizome was ground and each portion per subject contained $2 \mathrm{~g}$ of the powder dissolved in $15 \mathrm{ml}$ hot distilled water $\left(70^{\circ} \mathrm{C}\right)$

Identification of 10-gingerol and 6-shogaol in Z. officinale var. Rubrum suspension. Identification of 10-gingerol and 6-shogaol in $Z$. officinale var. Rubrum suspension was performed by dissolving the suspension in $15 \mathrm{ml}$ methanol hypergrade. The mixture was vortexed and centrifuged at $20,440 \times \mathrm{g}$ at room temperature for $15 \mathrm{~min}$. The supernatant was scanned at $200-380 \mathrm{~nm}$ in a double beam UV spectrophotometer against the methanol hypergrade its maximum wavelength $(\lambda \max )$ was compared with those of 10 -gingerol and 6-shogaol.

Preparation of 10-gingerol and 6-shogaol standard solutions. A total of $2.5 \mathrm{mg}$ of each of the 10-gingerol and 6-shogaol standards was dissolved in $100 \mathrm{ml}$ methanol hypergrade in a volumetric flask $(25 \mu \mathrm{g} / \mathrm{ml})$. The solutions were scanned at $200-380 \mathrm{~nm}$ in the double beam UV spectrophotometer against the methanol hypergrade to obtain the $\lambda$ max's of 10-gingerol and 6-shogaol. Various concentrations were prepared by diluting the standard solution (Tables I and II) (24).

Optimization of LC-MS analytical conditions. The 10-gingerol and 6-shogaol standard solutions (2.5, 5.0, 10.0, 15.0, 20.0 and $25.0 \mathrm{ng} / \mathrm{ml}$ ) were filtered using Millipore membranes (pore size $0.2 \mu \mathrm{m}$; EMD Millipore, Billerica, MA, USA) and injected into the LC-MS RP-C18 column. The optimized conditions of the LC-MS are presented in Table III.

\section{Validation of analytical method}

Selectivity. The selectivity of the method was investigated by comparing the chromatogram of extracted blank plasma $(3 \mathrm{ml})$ obtained from six randomly selected participants described below, each spiked with $25.0 \mathrm{ng} / \mathrm{ml} \mathrm{6-shogaol.}$

Linearity. Linearity of the standard curves was calculated using human plasma spiked with various concentrations $(2.5,5.0,10.0,15.0,20.0$ and $25.0 \mathrm{ng} / \mathrm{ml})$ of 10 -gingerol and 6-shogaol. The concentrations were plotted against the area under curves (AUCs) of the 10-gingerol and 6-shogaol chromatograms. The regression line $(y=a x+b)$ and the coefficient of correlation (r) of the data were calculated. 
Table I. Preparation of 10-gingerol standard solutions.

Final

$\begin{array}{lccc}\text { Blank } & \text { 10-gingerol, } & \text { Acetonitrile, } & \text { concentration, } \\ \text { plasma, } \mu 1 & \mu \mathrm{l} & \mu \mathrm{l} & \mathrm{ng} / \mathrm{ml}\end{array}$

\begin{tabular}{lrrr}
\hline 200 & - & 800.0 & Blank \\
200 & 2.5 & 797.5 & 2.5 \\
200 & 5.0 & 795.0 & 5.0 \\
200 & 10.0 & 790.0 & 10.0 \\
200 & 15.0 & 785.0 & 15.0 \\
200 & 20.0 & 780.0 & 20.0 \\
200 & 25.0 & 775.0 & 25.0 \\
\hline
\end{tabular}

Table II. Preparation of 6-shogaol standard solutions.

\begin{tabular}{lccc}
\hline Blank & & & Final \\
plasma, $\mu 1$ & $\begin{array}{c}\text { 6-shogaol, } \\
\mu 1\end{array}$ & $\begin{array}{c}\text { Acetonitrile, } \\
\mu 1\end{array}$ & $\begin{array}{c}\text { concentration, } \\
\mathrm{ng} / \mathrm{ml}\end{array}$ \\
\hline 200 & - & 800.0 & Blank \\
200 & 2.5 & 797.5 & 2.5 \\
200 & 5.0 & 795.0 & 5.0 \\
200 & 10.0 & 790.0 & 10.0 \\
200 & 15.0 & 785.0 & 15.0 \\
200 & 20.0 & 780.0 & 20.0 \\
200 & 25.0 & 775.0 & 25.0 \\
\hline
\end{tabular}<smiles>CCCCCCCCCC(O)CC(=O)CCc1ccc(O)c(OC)c1</smiles><smiles>CCCCC/C=C/C(=O)CCc1ccc(O)c(OC)c1</smiles>

Figure 1. Chemical structure of (A) 10-gingerol and (B) 6-shogaol, downloaded from http://www.chemspider.com/Chemical-Structure.147055.html? rid=a2e8c30f-67ff-43bb-9b9d-b526a54aae92\&page_num =0 for 10-gingerol and http://www.chemspider.com/Chemical-Structure.4445106.html?rid= aff2295b-35aa-43d5-807a-8b26311f4469 for 6-shogaol and redrawn using ChemDraw Professional 15.0.0.106 (PerkenElmer, Waltham, MA, USA licensed to Padjadjaran University, West Java, Indonesia, no. 623018920).

Accuracy and precision. The accuracy and precision of the method were evaluated by analyzing 10-gingerol and 6-shogaol in three sets of quality control samples [lower concentration of quality control $(\mathrm{LCQC})=2.5 \mathrm{ng} / \mathrm{ml}$; medium concentration of quality control $(\mathrm{MCQC})=15 \mathrm{ng} / \mathrm{ml}$; and higher concentration of quality control $(\mathrm{HCQC})=25 \mathrm{ng} / \mathrm{ml}$ each] within the same day. Each solution was injected into the column in three replicates. The percentage recovery and standard deviation (SD) were calculated to ascertain accuracy and precision of the analytical method, respectively.

Limit of detection (LOD) and limit of quantification (LOQ). The LOD and LOQ were calculated by using: $\mathrm{LOD}=(3 \mathrm{xSD}) / \mathrm{b}$; and $\mathrm{LOQ}=(10 \mathrm{xSD}) / \mathrm{b}$ where $\mathrm{b}$ is the $y$-intercept of the linear regression curve (25).

Subjects and treatment. A total of 21 participants ( 8 females and 13 males) aged 21-30 years, with body mass indices (BMIs) of 18-25, non-smokers and/or alcohol drinkers, were solicited by advertisement from May to September 2017. All participants were confirmed to be healthy by physical examination at Padjadjaran Clinic, Padjadjaran University (Jatinangor, Indonesia; Table IV). Two of the participants (R14 and R20) had low BP (90/60). Initially both were included in the study, but one of them (R14) vomited during the treatment, and was excluded. One of the participants (R21) was menstruating on the day of preliminary health screening and was excluded. The remaining 19 subjects continued the study. All study procedures were administered at the Faculty of Pharmacy, Padjadjaran University following collection of signed written informed consent according to the principles of the Declaration of Helsinki. The subject protocols and treatment were approved by the Research Ethics Committee of Padjadjaran University (approval nos. 1211/UN6.C.10/PN/2017 for 10-gingerol and 924/UN6.C.10/PN/2017 for 6-shogaol). The subjects were asked to avoid all foods containing ginger within 7 days prior to the project and completed a food checklist to verify that they were not consuming any ginger-rich food or beverages. All subjects received the Sundanese standard meal (one portion of white rice equivalent to $240 \mathrm{cal}, 100 \mathrm{~g}$ of fried chicken/tofu equivalent to $110-120 \mathrm{cal}$, hot tea equivalent to $70 \mathrm{cal}$, and a banana/orange 3 times/day at $24 \mathrm{~h}$ pre-study and for breakfast on the day of the study.

The red ginger suspension was administered the subsequent morning after the standard breakfast had been received. Each subject was given one portion of red ginger suspension $(2 \mathrm{~g}$ in $15 \mathrm{ml}$ of water) as a single oral dose, and $3 \mathrm{ml}$ blood samples were taken from the subjects at baseline ( $0 \mathrm{~min}), 30,60,90$, 120 and $180 \mathrm{~min}$. The blood was put into the K2EDTA vacutainer tubes. Plasma was separated by centrifuging at $20,440 \mathrm{x} \mathrm{g}$ for $15 \mathrm{~min}$ at room temperature and kept at $-20^{\circ} \mathrm{C}$ until assayed.

Pharmacokinetics of 10-gingerol and 6-shogaol. Analysis of 10-gingerol and 6-shogaol was performed by dissolving $200 \mu \mathrm{l}$ of the subjects' plasma in $800 \mu \mathrm{l}$ acetonitrile. The mixture was vortexed and centrifuged at 20,440 x g for $15 \mathrm{~min}$ at room temperature. The supernatant was filtered using Millipore membrane (pore size $0.2 \mu \mathrm{m}$ ) and injected into the RP-C18 column embedded in the LC-MS XEVO-QTOFMS.

\section{Results and Discussion}

Identification of 10-gingerol and 6-shogaol in Z. officinale var. Rubrum suspension. Gingerol and/or shogaol were indi- 
Table III. LC-MS optimum analytical conditions for 10-gingerol and 6-shogaol $\left(\mathrm{N}_{2}\right.$ gas temperature $350^{\circ} \mathrm{C}$; drying $\mathrm{N}_{2}$ gas flow rate $10 \mathrm{l} / \mathrm{min}$; nebulizer pressure $50 \mathrm{psi}$ ).

LC-MS parameter $\quad$ Setting condition

\section{Merk/Type}

Column

Mobile phase

Time setting (ratio phase A:phase B)

Flow rate; retention time

Mass spectrometer mode/ion detection

\section{Waters Xevo QTof -MassLynx 4.1 SCN719}

BEH Shield RP18 Ø $1.7 \mu \mathrm{m} ; 2.1$ x 100 mm

Phase A: $0.1 \%(\mathrm{v} / \mathrm{v})$ formic acid in water; phase B: acetonitrile

0-6th $\min (38: 62)$; 6-9th $\min (0: 100)$; 9-15th $\min (38: 62)$

$300 \mu \mathrm{l} / \mathrm{min} ; 15 \mathrm{~min}$

Electrospray ionization (ES+) ionization/multiple reaction monitoring mode

LC, liquid chromatography; MS, mass spectrometry.

Table IV. Preliminary health screening of the participants.

\begin{tabular}{|c|c|c|c|c|c|c|}
\hline \multirow[b]{2}{*}{ Subject code } & \multirow[b]{2}{*}{ Age, years } & \multicolumn{5}{|c|}{ Health status } \\
\hline & & Height, $\mathrm{cm}$ & Weight, $\mathrm{kg}$ & Blood type & $\mathrm{BP}, \mathrm{mmHg}$ & Result \\
\hline $\mathrm{R} 1$ & 22 & 160 & 63 & A & $120 / 80$ & Healthy \\
\hline $\mathrm{R} 2$ & 21 & 164 & 61 & $\mathrm{O}$ & $120 / 80$ & Healthy \\
\hline R3 & 21 & 176 & 72 & $\mathrm{AB}$ & $110 / 70$ & Healthy \\
\hline $\mathrm{R} 4$ & 22 & 164 & 64 & $\mathrm{~B}$ & $110 / 70$ & Healthy \\
\hline R5 & 22 & 175 & 63 & $\mathrm{O}$ & $120 / 80$ & Healthy \\
\hline R6 & 22 & 165 & 55 & A & $110 / 80$ & Healthy \\
\hline R7 & 22 & 172 & 56 & A & $110 / 70$ & Healthy \\
\hline R8 & 22 & 165.5 & 66 & $\mathrm{O}$ & $120 / 80$ & Healthy \\
\hline R9 & 22 & 164 & 55 & $\mathrm{O}$ & $100 / 60$ & Healthy \\
\hline $\mathrm{R} 10$ & 25 & 169 & 60 & $\mathrm{~B}$ & $120 / 80$ & Healthy \\
\hline $\mathrm{R} 11$ & 26 & 168 & 65 & $\mathrm{O}$ & $120 / 80$ & Healthy \\
\hline $\mathrm{R} 12$ & 30 & 161 & 58 & A & $100 / 70$ & Healthy \\
\hline $\mathrm{R} 13$ & 22 & 164 & 54 & A & $100 / 70$ & Healthy \\
\hline $\mathrm{R} 14$ & 23 & 157 & 65 & $\mathrm{O}$ & $90 / 60$ & Excluded $^{\mathrm{a}}$ \\
\hline $\mathrm{R} 15$ & 22 & 160.5 & 49 & $\mathrm{AB}$ & $100 / 70$ & Healthy \\
\hline R16 & 22 & 155 & 48 & $\mathrm{AB}$ & $120 / 80$ & Healthy \\
\hline $\mathrm{R} 17$ & 25 & 157 & 48 & $\mathrm{O}$ & $100 / 70$ & Healthy \\
\hline R18 & 25 & 145 & 45 & $\mathrm{O}$ & $100 / 80$ & Healthy \\
\hline R19 & 23 & 159 & 51 & $\mathrm{O}$ & $100 / 70$ & Healthy \\
\hline R20 & 22 & 155 & 44 & A & $90 / 60$ & Healthy \\
\hline $\mathrm{R} 21$ & 23 & 157 & 62 & B & $110 / 80$ & Excluded $^{\mathrm{b}}$ \\
\hline
\end{tabular}

a Due to low blood pressure and vomiting upon administration of red ginger suspension; bdue to menstruation at time of study.

cated to be present in the red ginger suspension by the $\lambda$ max of red ginger suspension in methanol $(\lambda \max =286 \mathrm{~nm})$ which was similar to those of 10-gingerol $(\lambda \max =284 \mathrm{~nm})$ and 6-shogaol $(\lambda \max =282$ nm; Fig. 2$)$.

Ethanol can extract gingerols more effectively than water; moreover, hot water is reportedly more effective than cold water (26). Ghasemzadeh et al (27) when working on the optimization procedure for the extraction of 6-gingerol and 6-shogaol (focusing on temperature $50-80^{\circ} \mathrm{C}$ and time 2-4 h) reported that increasing the extraction temperature (up to $76.9^{\circ} \mathrm{C}$ ) and time (3. h) induced the highest yield of 6-gingerol (2.74 mg/g dry weight) and 6-shogaol (1.59 mg/g dry weight) from $Z$. officinale var. Rubrum Theilade (27). The present work employed hot distilled water $\left(70^{\circ} \mathrm{C}\right)$ to extract $2 \mathrm{~g}$ of the red ginger ( $Z$. officinale var. Rubrum) powder.

Validation of analytical method. The LC-MS analytical method was selective for both 6-shogaol (Fig. 3) and 10-gingerol (Fig. 4) as proven by the respective chromatogram peaks that were free of interference at the retention time of 6-shogaol (6.70 $\mathrm{min})$ and 10-gingerol (8.26 min). The MS 

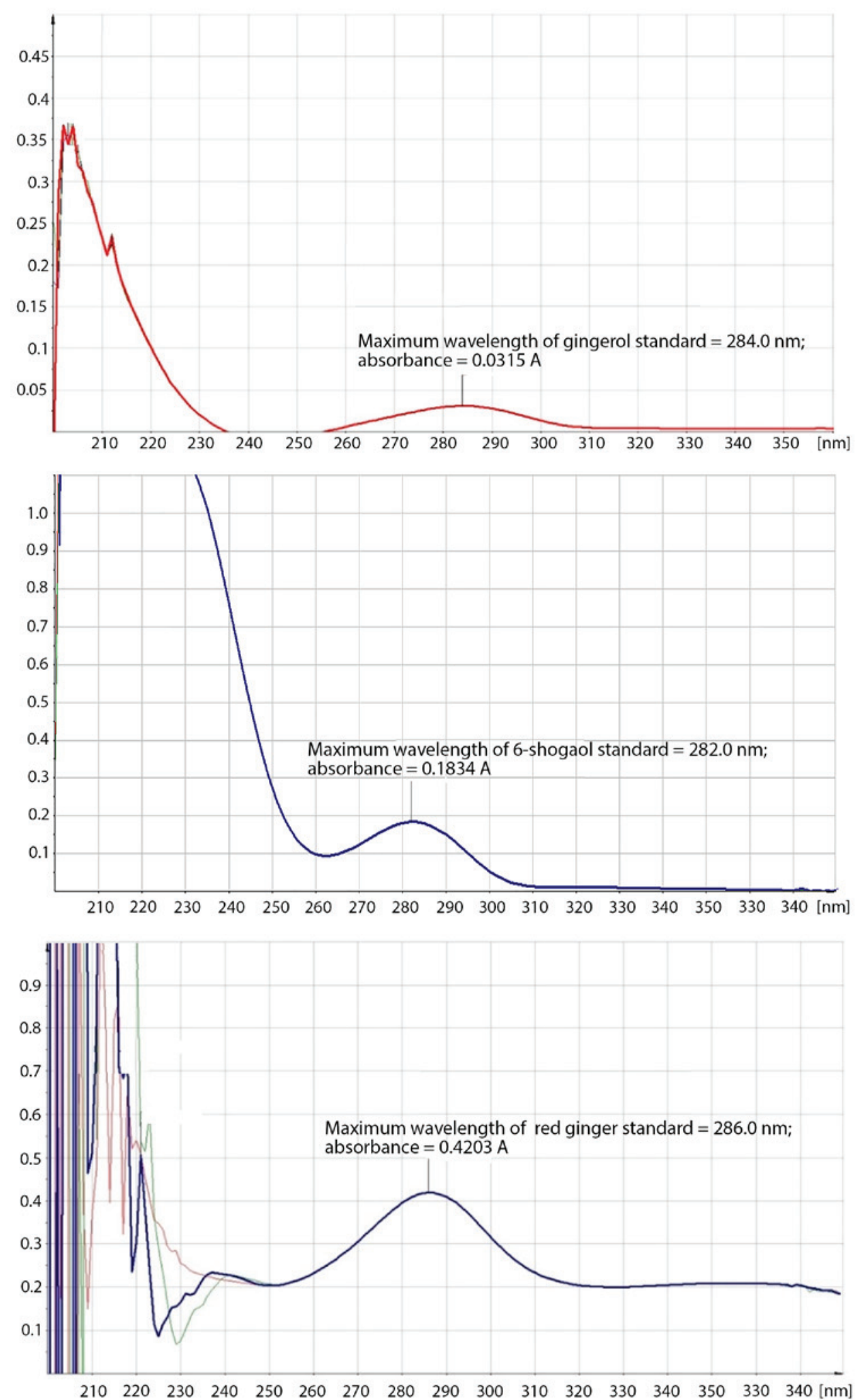

Figure 2. Ultraviolet spectra of 10 -gingerol standard $(\lambda \max =284 \mathrm{~nm} ; \mathrm{A}=0.0315) ; 6$-shogaol standard $(\lambda \max =282 \mathrm{~nm}$; $\mathrm{A}=0.1834)$; red ginger suspension $(\lambda \max =286 \mathrm{~nm} ; \mathrm{A}=0.4203) . \lambda \max$, maximum wavelength; $\mathrm{A}$, absorbance.

spectrum confirmed and correlated the chromatogram peak with the mass-to-charge ratio $(\mathrm{m} / \mathrm{z})$. Our MS spectra indicated the base peak of 6 -shogaol $[\mathrm{M}+1](\mathrm{m} / \mathrm{z}=277.3869$; MW 6-shogaol=276.376); and the base peak of 10-gingerol $[\mathrm{M}+1]$ $(\mathrm{m} / \mathrm{z}=351.2959 ; \mathrm{MW}$ 10-gingerol=350.4923).
Linearity of the standard curves was constructed using human plasma spiked with various concentrations $(2.5,5.0$, 10.0, 15.0, 20.0 and $25.0 \mathrm{ng} / \mathrm{ml}$ ) of 10-gingerol and 6-shogaol (Fig. 5). The LCQC $(2.5 \mathrm{ng} / \mathrm{ml})$, MCQC $(15.0 \mathrm{ng} / \mathrm{ml})$ and HCQC $(25.0 \mathrm{ng} / \mathrm{ml})$ of the ginger analytes were assayed 

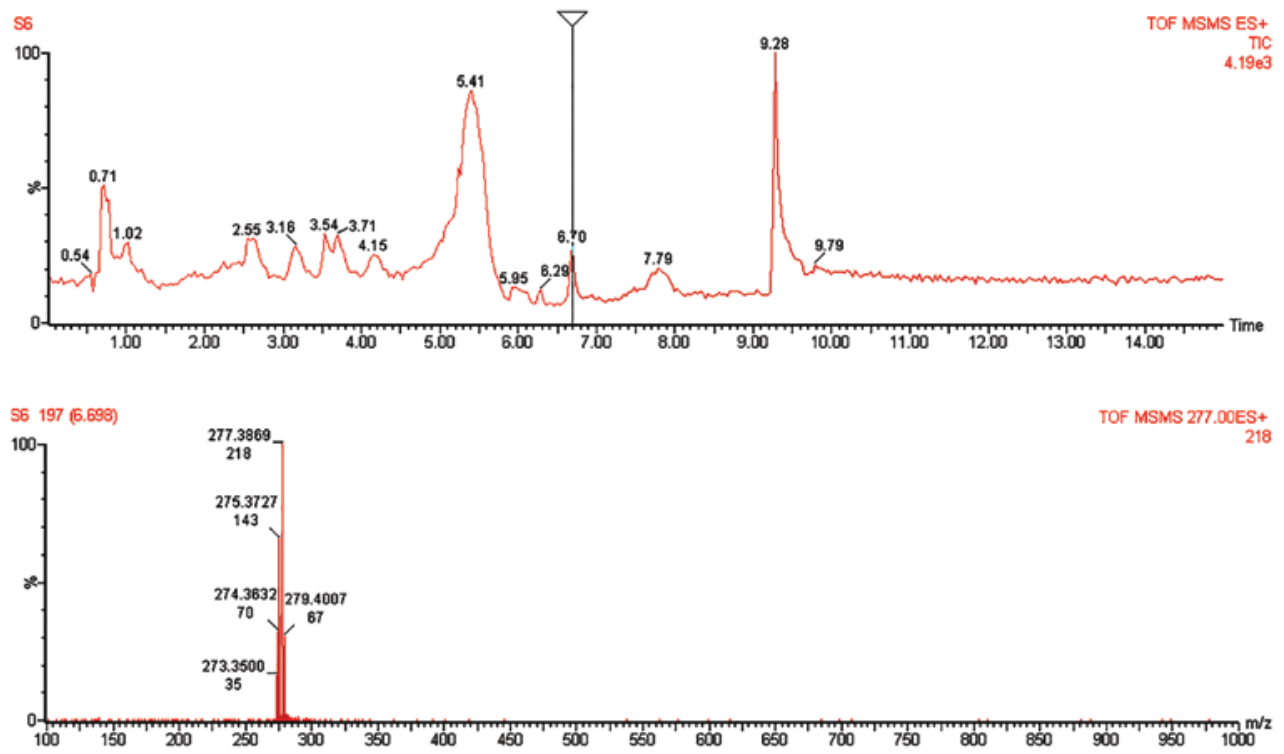

Figure 3. Representative chromatogram of human plasma spiked with 6-shogaol standard (retention time=6.70 min) (upper panel); and the mass spectrum of 6-shogaol $[\mathrm{M}+1](\mathrm{m} / \mathrm{z}=277.3869 ;$ MW 6-shogaol=276.376) (lower panel).
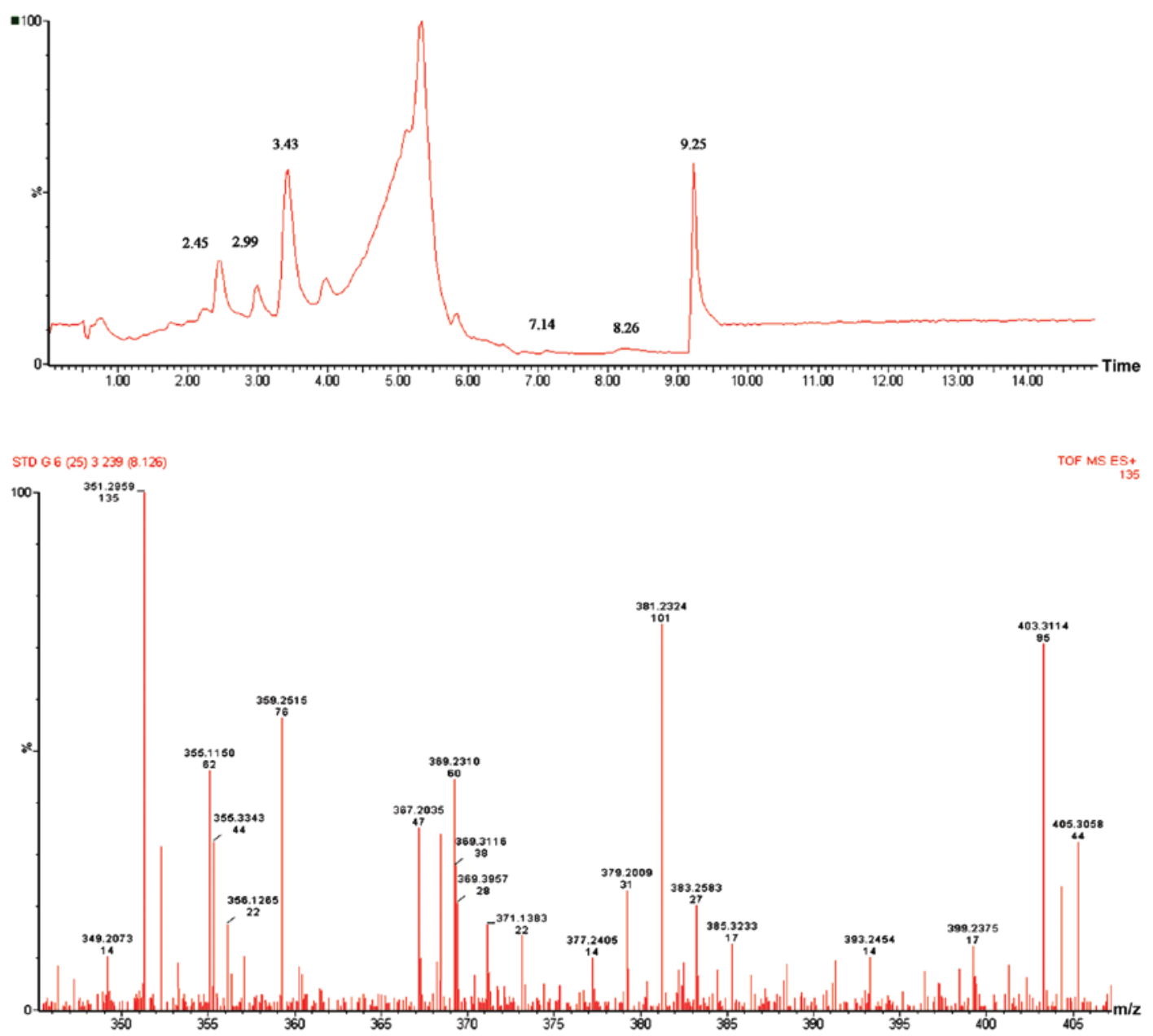

Figure 4. Representative chromatogram of human plasma spiked with 10-gingerol standard (retention time=8.26 min) (upper panel); and the mass spectrum of 10-gingerol $[\mathrm{M}+1](\mathrm{m} / \mathrm{z}=351.2959$; MW 10-gingerol=350.4923) (lower panel).

on an intra-day basis to determine the accuracy and precision of the method. The intra-day values for the SD ranged from 0.16-0.69 for 10-gingerol and 0.74-1.49 for 6-shogaol, whereas the recovery of the analytes was $100.64-104.44 \%$ for 10-gingerol and 103.40-104.22\% for 6-shogaol. The data (plot of AUC of the chromatogram peak against the concentration 


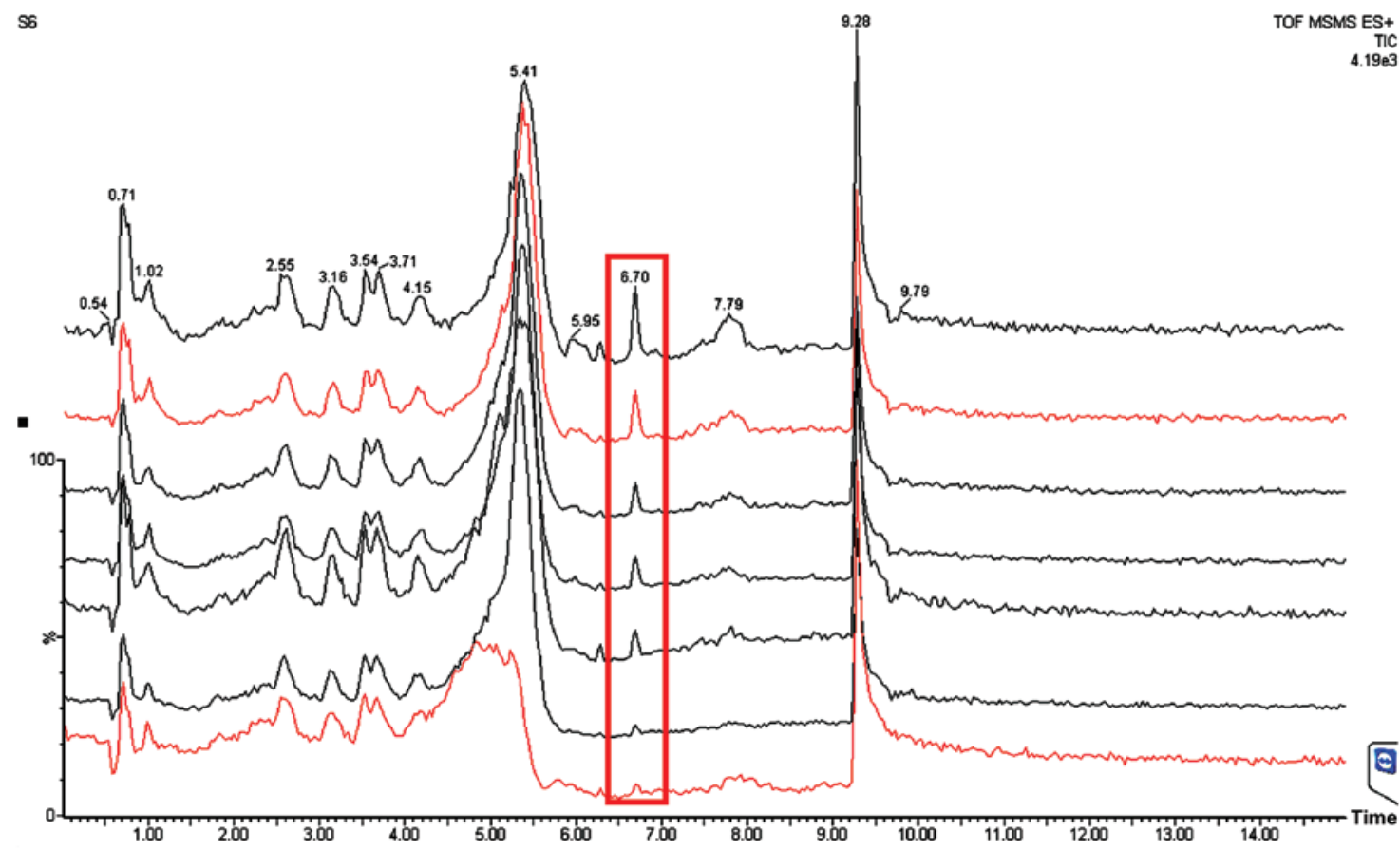

Figure 5. Chromatograms of human plasma spiked with various concentrations of 6 -shogaol standard (retention time=6.70 min).

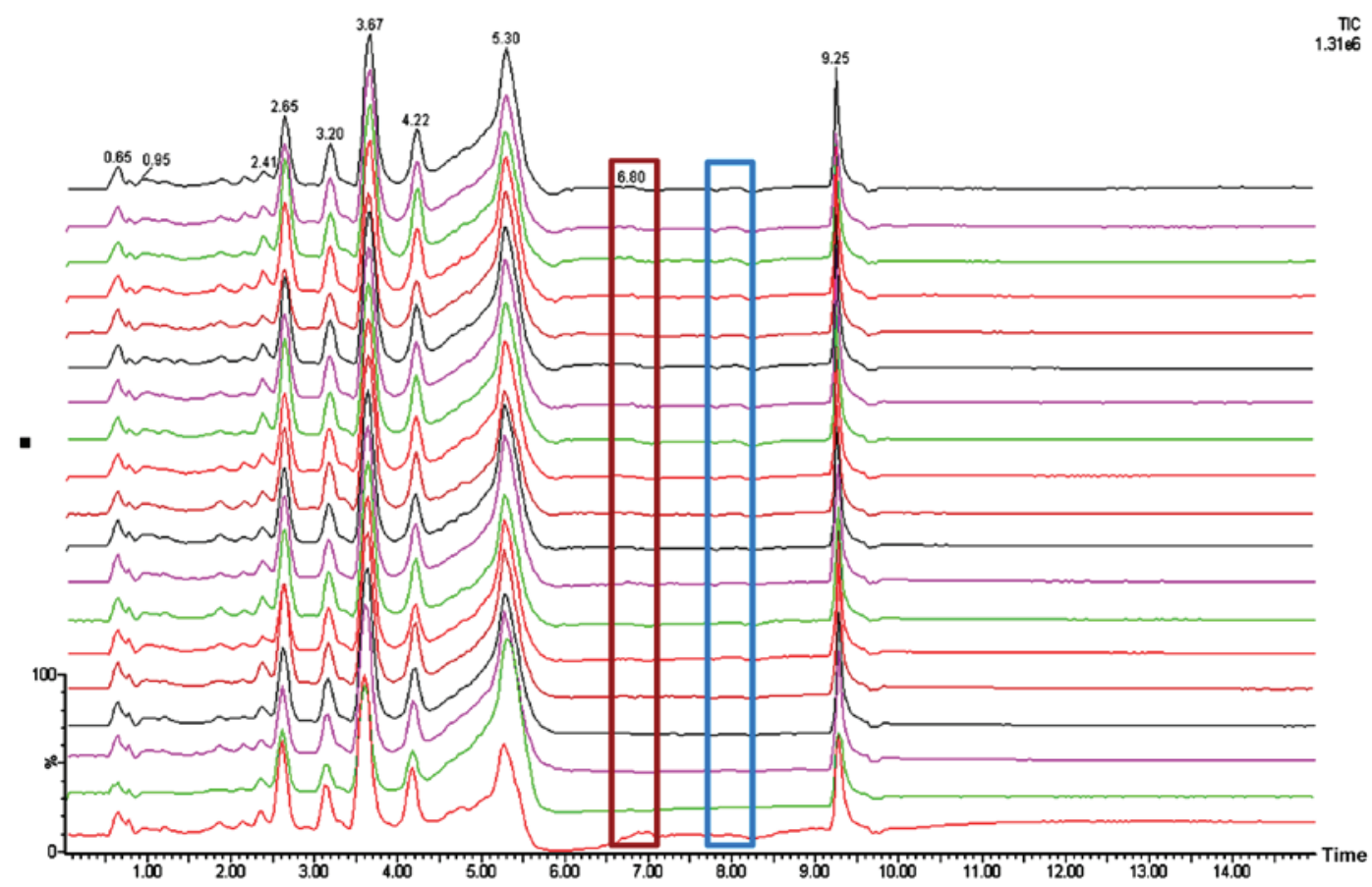

Figure 6. Chromatograms of 10-gingerol (blue rectangle; $t_{R}=8.0 \mathrm{~min}$ ) and 6-shogaol (red rectangle; $t_{R}=6.80 \mathrm{~min}$ ) in the plasma of 19 subjects after 30 min treatment with red ginger suspension. A mixture of $0.1 \%(\mathrm{v} / \mathrm{v})$ formic acid in water and acetonitrile $(38: 62)$ was used asthe mobile phase. $\mathrm{t}_{\mathrm{R}}$, retention time.

of 10-gingerol/6-shogaol; not shown) correlated as indicated by $\mathrm{r}$ values $>0.99$ (Table $\mathrm{V}$ ).

The LODs in human plasma for 10-gingerol and 6-shogaol were 1.31 and $1.51 \mathrm{ng} / \mathrm{ml}$, respectively, and the LOQs were 4.36 and $5.03 \mathrm{ng} / \mathrm{ml}$, respectively.

Characteristics of the subjects. All 19 subjects who completed the study were proven healthy by a physical examination upon enrollment (Table IV); however, 3-6 months prior to the start of the study, several subjects had suffered from gastritis $(1 / 19$; $5.26 \%)$, allergy $(7 / 19 ; 3.68 \%$; cold urticaria and/or seafood allergy), joint arthritis $(1 / 19 ; 5.26 \%)$ and dengue hemorrhagic fever $(1 / 19 ; 5.26 \%)$. The subjects also confirmed their weekly exercise as jogging and walking $(7 / 19 ; 3.68 \%)$, football $(2 / 19$; $10.53 \%)$ and badminton $(1 / 19 ; 5.26 \%)$.

Pharmacokinetics of 10-gingerol and 6-shogaol. 10-gingerol and 6-shogaol could be quantified in the plasma of healthy 
Table V. Validation of the 10-gingerol and 6-shogaol analytical method.

\begin{tabular}{|c|c|c|c|c|c|}
\hline $\begin{array}{l}\text { Concentration of } \\
\text { analyte, } \mathrm{ng} / \mathrm{ml}\end{array}$ & $\begin{array}{l}\text { Mean concentration, } \\
\mathrm{ng} / \mathrm{ml}\end{array}$ & $\begin{array}{l}\text { Standard } \\
\text { deviation }\end{array}$ & Recovery, \% & $\begin{array}{l}\text { Coefficient of } \\
\text { correlation (r) }\end{array}$ & Slope \\
\hline \multicolumn{6}{|l|}{ 10-gingerol } \\
\hline 2.5 & 2.53 & 0.16 & 101.28 & \multirow{3}{*}{0.9991} & \multirow{3}{*}{6.3195} \\
\hline 15.0 & 15.67 & 0.57 & 104.44 & & \\
\hline 25.0 & 26.16 & 0.69 & 100.64 & & \\
\hline \multicolumn{6}{|l|}{ 6-shogaol } \\
\hline 2.5 & 2.59 & 0.74 & 103.40 & \multirow{3}{*}{0.9987} & \multirow{3}{*}{2.7070} \\
\hline 15.0 & 15.63 & 1.49 & 104.22 & & \\
\hline 25.0 & 26.04 & 0.78 & 104.14 & & \\
\hline
\end{tabular}

Table VI. Pharmacokinetic profile of 10-gingerol and 6-shogaol in the plasma of healthy subjects treated with a single dose of red ginger suspension.

\begin{tabular}{lcc}
\hline Parameter $(\mathrm{n}=19)$ & 10-gingerol & 6-shogaol \\
\hline AUC, $\mathrm{ng} / \mathrm{ml} / \mathrm{min}$ & 948.750 & 268.140 \\
Cmax, $\mathrm{ng} / \mathrm{ml}$ & 160.49 & 453.40 \\
Tmax, min & 38 & 30 \\
T1² elimination, min & 336 & 149 \\
\hline
\end{tabular}

AUC, area under the curve; Cmax, maximum plasma concentration; Tmax, time to reach Cmax; $\mathrm{T}^{1 / 2}$, elimination half-life.

subjects treated with a single dose of red ginger suspension. They were eluted at $6.80 \mathrm{~min}(6$-shogaol) and $8.0 \mathrm{~min}$ (10-gingerol; Fig. 6), compared with the pure compounds (for 6-shogaol, $6.70 \mathrm{~min}$ and for 10-gingerol, $8.26 \mathrm{~min}$; Figs. 3 and 4), respectively. There was a slight difference of elution time between the standards (pure 6-shogaol and 10-gingerol compounds) and that of red ginger suspension due to different conditions; the standards were spiked in vitro into human plasma, while the red ginger suspension was administered orally and taken ex vivo from the subjects' blood. The pharmacokinetic profile of each of the red ginger compounds is presented in Table VI.

According to elimination half-lives ( $\left.\mathrm{T}^{1} 12\right), 10$-gingerol and 6-shogaol were eliminated from the plasma at 336 and $149 \mathrm{~min}$, respectively (Table VI). The maximum plasma concentration (Cmax) of 10-gingerol $(160.49 \mathrm{ng} / \mathrm{ml})$ was lower than that of 6-shogaol (453.40 ng/ml; Table VI).

These findings were different to those of Zick et al (22) who studied the pharmacokinetic profile of 6-, 8- and 10-gingerol and 6-shogaol in dry extract of ginger at doses of $100 \mathrm{mg}$ to $2 \mathrm{~g}$ in 27 healthy American participants (9 males, 22 females, mostly Caucasians). They identified that no free 6-, 8-, 10-gingerol or 6-shogaol was present, but 6-, 8- and 10 -gingerol and 6-shogaol glucuronides were detected. Furthermore, in the plasma of healthy Caucasians, the concentration of 10-gingerol has been quantified higher than that of 6-shogaol (23).

The present study used a single dose $(2 \mathrm{~g})$ of red ginger (Z. officinale var. Rubrum) suspension, administered orally to
19 healthy Indonesian participants (13 males and 6 females). Both 10-gingerol and 6-shogaol could be detected and quantified. In the plasma of the healthy Indonesians, 10-gingerol was quantified to a lower level than 6-shogaol.

10-gingerol and 6-shogaol exhibited slower elimination in Indonesian subjects compared with that in Caucasians ( $\mathrm{T}^{1 / 2}$ elimination $<120 \mathrm{~min}$ ). In the current study, no serious adverse effects were reported following ingestion of the red ginger suspension, though several female subjects complained of the potent pungent odor and spicy taste that caused stomach discomfort. These mild adverse effects were consistent with those reported by Zick et al (22) and in a previous review study by Chrubasik et al (28), who documented that the majority of the disadvantages were transient gastrointestinal reactions, such as gas and bloating.

In conclusion, 10-gingerol and 6-shogaol were absorbed after per oral single dose of red ginger suspension and could be quantified in the plasma of healthy Indonesian subjects. The Cmax of 10-gingerol $(160.49 \mathrm{ng} / \mathrm{ml})$ was lower than that of 6-shogaol $(453.40 \mathrm{ng} / \mathrm{ml})$. Notably, the two red ginger analytes exhibited relatively slow elimination half-lives. In the present trial, no serious adverse effects were reported following ingestion of the red ginger suspension, but several female subjects complained about the potent pungent odor and spicy taste that caused stomach discomfort. Overall, the present pharmacokinetic findings of 10-gingerol and 6-shogaol in Indonesian subjects confirmed that different ethnicities may contribute to different pharmacokinetic profiles. Identification of these differences may lead to personalized-medicine, and thus contribute in a clinical context, particularly in the discovery and development of anti-inflammatory drugs.

\section{Acknowledgements}

The authors would like to thank Professor Tri Hanggono Achmad, Rector of Universitas Padjadjaran (West Java, Indonesia) for facilitating and supporting this research project. The present work was conducted in the framework of the master theses of DMS and RDS at the Faculty of Pharmacy, Padjadjaran University, Jatinangor, West Java, Indonesia. The authors are also thankful to Dr. Joko Kusmoro at the Laboratory of Plant Taxonomy, Department of Biology, Faculty 
of Mathematics and Natural Sciences, Padjadjaran University, for identifying the plant specimen.

\section{Funding}

The present study was funded by the Academic-Leadership Grant Universitas Padjadjaran Batch-II 2017, research contract no. 872/UN6.3.1/LT/2017.

\section{Availability of data and materials}

The datasets used and/or analyzed in the current work are available from the corresponding author on reasonable request.

\section{Authors' contributions}

$\mathrm{JL}$ and $\mathrm{AD}$ were principally responsible for conception and design of the study. JL, MM and AD participated in the acquisition of the reported data. DMS, RDS, SM and MF participated in the processing, analysis and interpretation of the reported data. JL and SM contributed to the writing and revising of the manuscript. All authors read and approved the final manuscript to be published.

\section{Ethics approval and consent to participate}

Written informed consent was obtained from all participants. Research Ethics Committee of Padjadjaran University (Bandung, Indonesia) approved the study procedures (approval nos. 1211/UN6.C.10/PN/2017 for 10-gingerol and 924/UN6.C.10/PN/2017 for 6-shogaol).

\section{Patient consent for publication}

Informed consent was obtained for publication of the participants' data.

\section{Competing interests}

The authors declare that they have no competing interests.

\section{References}

1. Zhang X, Iwaoka WT, Huang AS, Nakamoto ST and Wong R: Gingerol decreases after processing and storage of ginger. J Food Sci 59: 1338-1340, 1994

2. Hiserodt RD, Franzblau SG and Rosen RT: Isolation of 6-, 8-, and 10-gingerol from ginger rhizome by HPLC and preliminary evaluation of inhibition of Mycobacterium avium and Mycobacterium tuberculosis. J Agric Food Chem 46: 2504-2508, 1998.

3. Young HY, Chiang CT, Huang YL, Pan FP and Chen GL: Analytical and stability studies of ginger preparations. Yao Wu Shi Pin Fen Xi 10: 149-153, 2002.

4. Riaz H, Begum A, Raza SA, Khan ZMUD, Yousaf H and Tariq A: Antimicrobial property and phytochemical study of ginger found in local area of Punjab, Pakistan. Int Curr Pharm J 4: 405-409, 2015.

5. Ugwoke CEC and Nzekwe U: Phytochemistry and proximate composition of ginger (Zingiber officinale). J Pharm Allied Sci 7 : No. 5, 2010.

6. Bhargava S, Dhabhai K, Amla Batra A, Sharma A and Malhotra B: Zingiber officinale: Chemical and phytochemical screening and evaluation of its antimicrobial activities. J Chem Pharm Res 4: 360-364, 2012.

7. Prasad S and Tyagi AK: Ginger and its constituents: Role in prevention and treatment of gastrointestinal cancer. Gastroenterol Res Pract 2015: 142979, 2015.
8. Marrelli M, Menichini F and Conforti F: A comparative study of Zingiber officinale Roscoe pulp and peel: Phytochemical composition and evaluation of antitumour activity. Nat Prod Res 29: 2045-2049, 2015

9. Mashhadi NS, Ghiasvand R, Askari G, Hariri M, Darvishi L and Mofid MR: Anti-oxidative and anti-inflammatory effects of ginger in health and physical activity: Review of current evidence. Int J Prev Med 4 (Suppl 1): S36-S42, 2013.

10. Dhanik J, Arya N and Nand V: A review on Zingiber officinale. J Pharmacogn Phytochem 6: 174-184, 2017.

11. Jiang H, Sólyom AM, Timmermann BN and Gang DR: Characterization of gingerol-related compounds in ginger rhizome (Zingiber officinale Rosc.) by high-performance liquid chromatography/electrospray ionization mass spectrometry. Rapid Commun Mass Spectrom 19: 2957-2964, 2005.

12. Tjendraputra E, Tran VH, Liu-Brennan D, Roufogalis BD and Duke CC: Effect of ginger constituents and synthetic analogues on cyclooxygenase- 2 enzyme in intact cells. Bioorg Chem 29: 156-163, 2001.

13. Afzal M, Al-Hadidi D, Menon M, Pesek J and Dhami MSI Ginger: An ethnomedical, chemical and pharmacological review. Drug Metab Drug Interact 18: 159-190, 2001.

14. Grzanna R, Phan P, Polotsky A, Lindmark L and Frondoza CG: Ginger extract inhibits beta-amyloid peptide-induced cytokine and chemokine expression in cultured THP-1 monocytes. J Altern Complement Med 10: 1009-1013, 2004.

15. Lantz RC, Chen GJ, Sarihan M, Sólyom AM, Jolad SD and Timmermann BN: The effect of extracts from ginger rhizome on inflammatory mediator production. Phytomedicine 14: 123-128, 2007.

16. Ghasemzadeh A, Jaafar HZ and Rahmat A: Variation of the phytochemical constituents and antioxidant activities of Zingiber officinale var. Rubrum Theilade associated with different drying methods and polyphenol oxidase activity. Molecules 21: 780, 2016.

17. Dugasani S,Pichika MR, Nadarajah VD, Balijepalli MK, Tandra S and Korlakunta JN: Comparative antioxidant and anti-inflammatory effects of [6]-gingerol, [8]-gingerol, [10]-gingerol and [6]-shogaol. J Ethnopharmacol 127: 515-520, 2010.

18. Ippoushi $\mathrm{K}$, Azuma $\mathrm{K}$, Ito $\mathrm{H}$, Horie $\mathrm{H}$ and Higashio $\mathrm{H}$ : [6]-Gingerol inhibits nitric oxide synthesis in activated J774.1 mouse macrophages and prevents peroxynitrite-induced oxidation and nitration reactions. Life Sci 73: 3427-3437, 2003.

19. Kim SO, Kundu JK, Shin YK, Park JH, Cho MH, Kim TY and Surh YJ: [6]-Gingerol inhibits COX-2 expression by blocking the activation of $\mathrm{p} 38$ MAP kinase and NF-kappaB in phorbol ester-stimulated mouse skin. Oncogene 24: 2558-2567, 2005.

20. Fikri F, Saptarini NM, Levita J, Nawawi A, Mutalib A and Ibrahim S: The inhibitory activity on the rate of prostaglandin production by Zingiber officinale var. Rubrum. Pharmacol Clin Pharm Res 1: 33-40, 2016.

21. Saptarini NM, Sitorus EY and Levita J: Structure-based in silico study of 6-gingerol, 6-ghogaol, and 6-paradol, active compounds of ginger (Zingiber officinale) as COX-2 inhibitors. Int J Chem 5: 12-18, 2013

22. Zick SM, Djuric Z, Ruffin MT, Litzinger AJ, Normolle DP, Alrawi S, Feng MR and Brenner DE: Pharmacokinetics of 6-gingerol, 8-gingerol, 10-gingerol, and 6-shogaol and conjugate metabolites in healthy human subjects. Cancer Epidemiol Biomarkers Prev 17: 1930-1936, 2008.

23. Yu Y, Zick S, Li X, Zou P, Wright B and Sun D: Examination of the pharmacokinetics of active ingredients of ginger in humans. AAPS J 13: 417-426, 2011.

24. Zick SM, Ruffin MT, Djuric Z, Normolle D and Brenner DE: Quantitation of 6-, 8-, and 10-gingerols and 6-shogaol in human plasma by high-performance liquid chromatography with electrochemical detection. Int J Biomed Sci 6: 233-240, 2010.

25. Şengül Ü: Comparing determination methods of detection and quantification limits for aflatoxin analysis in hazelnut. Yao $\mathrm{Wu}$ Shi Pin Fen Xi 24: 56-62, 2016.

26. Wohlmuth H: Phytochemistry and pharmacology of plants from the ginger family, Zingiberaceae (unpublished PhD thesis). Southern Cross University, Lismore, New South Wales, 2008.

27. Ghasemzadeh A, Jaafar HZ and Rahmat A: Optimization protocol for the extraction of 6-gingerol and 6-shogaol from Zingiber officinale var. rubrum Theilade and improving antioxidant and anticancer activity using response surface methodology. BMC Complement Altern Med 15: 258, 2015.

28. Chrubasik S, Pittler MH and Roufogalis BD: Zingiberis rhizoma: A comprehensive review on the ginger effect and efficacy profiles. Phytomedicine 12: 684-701, 2005. 